\title{
Article
}

\section{Taming SOEs within a Redefined Competition Policy Framework: An Alternative Approach for Consensus?*}

\author{
Pinguang Ying ${ }^{* *}$
}

With the growing concern of the international community about the negative spillover effects of SOEs on trade, reaching a consensus among different stakeholders has become increasingly urgent. This paper argues that strengthening a redefined competition policy is a feasible alternative, or at least a complementary option to the existing trade framework. The reasons are as follows: (a) surrounding SOEs is not only trade-related, but also competition-related; (b) the existing SOE disciplines have defects when it comes to dealing with competition distortion effects; and (c) characteristics of competition policy make it easier to reach a "maximum common divisor" among all parties. Accordingly, competition policy needs to be redefined and pursued from an international and domestic level. It is necessary to strengthen the fundamental position of competition policy in China by integrating it into SOE reform measures, advancing the implementation of the Fair Competition Review System, and promoting the construction of the competitive neutrality system.

* This article is an intermediate outcome of a research project on the China's Fair Competition Review System sponsored by the Development Research Center of the State Administration for Market Regulation. An earlier version of this article was presented at the WTO Chairs Annual Conference 2019, Geneva on July 1, 2019.

** Associate Professor at the WTO Chair Institute-China \& the School of Trade Negotiations, Shanghai University of International Business and Economics (SUIBE); Deputy Director of the Shanghai Centre for Global Trade and Economic Governance (SC-GTEG); Postdoctoral Fellow of the Vrije Universiteit Brussel (VUB). B.A./M.A. (Sichuan Univ.), Ph.D. (ECUPL). ORCID: https://orcid.org/0000-0002-9518-6922. The author may be contacted at: yingpinguang@suibe. edu.cn/Address: 620 Gubei Road, Shanghai 200336, P.R. China. The author is grateful to Hui Chen for valuable research assistance.

All the websites cited in this article were last visited on February 15, 2020. 
Keywords: SOEs, Competition Policy, Trade Policy, Fair Competition Review, Competitive Neutrality

\section{INTRODUCTION}

In recent years, the main trading economies, including the United States ("US"), the European Union ("EU") ${ }^{2}$ and Japan, have, individually or jointly, ${ }^{3}$ issued numerous reports or statements, accusing China of using State-owned Enterprise ("SOEs") to distort global trade. SOEs are criticized mainly because they are controlled by the government. SOEs are operating as a tool of government policies and enjoying inherent competitive privileges "such as preferential access to finances, protection by market access restrictions, preferential access to land, energy, etc."4 Besides, SOEs, "especially those that are uncorporatized, are often burdened with unincentivized top management, with very limited accountability but with decisionmaking concentrated in a limited amount of hands." All these features are not conducive to the effective allocation of resources and hinder a level playing field. Therefore, at the multilateral level, they call for reforming and advancing the current WTO disciplines related to SOEs, especially those concerning subsidies and transparency. At the bilateral or regional level, they have led and concluded a number of trade agreements, including the Comprehensive and Progressive Agreement for Trans-Pacific Partnership ("CPTPP"), the US-Mexico-Canada Agreement ("USMCA"), the Comprehensive and Economic Trade Agreement ("CETA"), and the EU-Japan Economic Partnership Agreement ("EPA"), all of which incorporate specific chapters on SOEs. Given that the US is a member of the USMCA, Japan is a member of the CPTPP, and the EPA is concluded between the EU and Japan, they can easily reach a consensus about how to "rewrite international rules" for SOEs.

However, China is demonstratively opposed to the above claims. In its Proposal on the WTO Reform, China states explicitly that "SOEs engaged in commercial competition are equal players in the market as other types of enterprises," and condemns any "set[ting] forth special or discriminatory disciplines on SOEs in the name of WTO reform." Additionally, except for the existing WTO multilateral rules, China has not accepted the integration of any special SOE chapter or 
disciplines into the free trade agreements it participates in.

Therefore, there is a big discrepancy between China and other major economies' understanding of issues surrounding SOEs. Accordingly, this article attempts to address the following question: how can a certain degree of consensus be reached on solving the trade distortions of SOEs?

This paper is composed of five parts including an Introduction and Conclusion. Part two will briefly explore the existing SOE disciplines at multilateral, regional or bilateral levels. Part three will examine China's experience in restricting the unfair competitive advantages of SOEs at both the international and domestic levels. Part four will argue that a redefined competition policy framework can serve as an alternative or supplementary approach for maximizing the integration of various positions of all parties. It further submits that the definition, scope and advocacy path of competition policy need to be re-adjusted, so as to meet the needs of all parties and solve the problem of competition distortion that SOEs pose.

\section{SOE DiSCIPLINES AT THE INTERNATIONAL LEVEL}

\section{A. Traditional Disciplines}

There are no specific provisions for SOEs within the framework of GATT/WTO, but the rules concerning state trading enterprises ("STEs"), which are mainly embodied in Article XVII of the General Agreement on Tariffs and Trade ("GATT"), provide a basic framework for regulating trade behaviors of SOEs.

STE rules provide a general definition of STEs. ${ }^{7}$ According to these rules, STEs include not only governmental enterprises, but also non-governmental enterprises, as long as they benefit from "exclusive or special privileges." Nevertheless, the definition does not provide a specific and clear criterion for identifying SOEs. STE rules also impose two basic obligations by requiring Members to ensure STEs to (a) act in a manner consistent with the general principles of non-discriminatory treatment, and (b) make purchases or sales solely in accordance with commercial considerations. But the non-discriminatory treatment obligation applies only to 'governmental' measures and excludes corporate acts, especially that of SOEs; and whether it covers obligations involving national treatment is unclear, ${ }^{8}$ though it definitely does include most favored nation ("MFN") treatment. Likewise, there is 
no additional explanation on how to determine a commercial consideration, though some applicable conditions, such as "price, quality, availability, marketability, transportation, and other conditions of purchase or sale," are provided.

Moreover, the above obligations apply only to STEs that participate in international trade, i.e., "in its purchases or sales involving either imports or exports." Therefore, if STEs are suppliers of products or services within their domestic market, they are not subject to the above obligations even if they impact global trade. Furthermore, STE rules set out very limited transparency obligations by requiring Members to notify, on their own initiative or upon request of other parties, information on STEs regarding imported or exported products, operations and products' mark-up. However, since this is only a notification obligation, the transparency requirement is fairly preliminary: no remedies or penalties are imposed upon the absence of a full compliance with the notification obligations. ${ }^{10}$

In addition, there are rules indirectly related to SOEs, for example, the provisions on monopoly suppliers and exclusive service suppliers in the General Agreement on Trade in Services ("GATS"), and the subsidy rules in the Agreement on Subsidies and Countervailing Measures ("SCM Agreement").

The GATS has a narrower scope than the GATT because it only applies to monopoly suppliers and exclusive service suppliers. ${ }^{11}$ In terms of the obligations it imposes, though MFN treatment is involved comprehensively, national treatment is restricted to limited sectors where a Member has made specific commitments. ${ }^{12}$ It also involves only limited transparency requirements and is widely criticized for poor performance. ${ }^{13}$

The SCM Agreement does not apply directly to SOEs. However, an SOE may be identified as a "public body" and thus be subject to the SCM Agreement. There have been quite a few such cases brought to the WTO Dispute Settlement Body ("DSB"), whose Panel and Appellate Body have made some clarifications regarding the circumstances under which SOEs may constitute public bodies. ${ }^{14}$ They concluded that the critical criterion in identifying a public body is whether an entity has an "authority to perform governmental functions," rather than mere evidence of majority government ownership. ${ }^{15}$ Despite this position, in a recent case, ${ }^{16}$ the Appellate Body pointed out that the identification of a public body does not require a focus on every instance of conduct engaged by that entity or its connection to a specific "government function," but rather on the systemic influence of the 
government in, and its relationship with that investigated entity. To a certain extent, this relaxes the criteria for recognizing a SOE as a public body. The judgment of whether a SOE constitutes a public body remains only based on case analysis. In other words, it cannot be concluded that SOEs as such are public bodies.

Therefore, the traditional disciplines are primarily regarded as not sufficient to solve trade distortion problems of SOEs because of their unclear definition for SOEs, the limited scope of application (only applicable to goods and very limited services), poor implementation of transparency requirements, and a deficient link between subsidy rules and SOEs rules. Thus, the so-called 21st-century disciplines emerged as additional rules for regulating SOEs.

\section{B. The 21st Century Disciplines}

As the CPTPP and the USMCA are the most detailed, comprehensive and indepth trade agreements concerning SOE disciplines to date, the following section will primarily use them as typical examples to analyze the improvement of new disciplines and ask whether they can serve as meaningful methods for dispelling the concerns posed by SOEs.

First, they clarify the definition and expand the coverage of SOEs. Article 17.1 of the CPTPP defines SOEs as enterprises that are principally engaged in commercial activities in which the government 'directly' holds more than 50 percent of the share capital or voting rights, or the power to appoint a majority of members of the board of directors or any other equivalent management body. ${ }^{17}$ Article 22.1 of the USMCA further expands the scope of SOEs to any enterprise that the government 'indirectly' ${ }^{18}$ owns more than 50 percent of the share capital or voting rights of, or holds the power to control the enterprise through any other ownership interest, including indirect or minority ownership. Besides, a designated monopoly, which is defined as a privately owned monopoly or a government monopoly designated by the government, ${ }^{19}$ is introduced in both agreements as a complementary terminology to cover all kinds of monopoly powers due to government intervention. In brief, as long as the government constitutes effective control over an enterprise, whether through determining or affecting significant matters of the enterprise, or through indirect control or a minority stake in it, that enterprise may be regarded as an SOE.

Second, they reaffirm and expand the coverage of basic obligations such as non- 
discriminatory treatment and commercial considerations. Both the CPTPP and the USMCA clarify that non-discrimination includes not only MFN treatment, but also national treatment, ${ }^{20}$ which avoids the confusion existing in Article XVII of the GATT. Moreover, they give a clearer definition of commercial considerations by providing an additional explanation. ${ }^{21}$ According to this explanation, an important test for determining commercial considerations is whether an SOE can obtain rates of return equivalent to that of private enterprises. Furthermore, their coverage of non-discrimination treatment and commercial considerations extends not only to the sale and purchase of goods, but also to services, including when supplied as an investment in a Party's territory. ${ }^{22}$ They further enlarge the influence of SOEs disciplines by indicating that these obligations also apply to the activities of SOEs of a Party that cause adverse effects in the market of a non-Party. ${ }^{23}$

Third, they strengthen the transparency obligations with a more systematic and comprehensive disclosure requirement. Both the CPTPP and the USMCA require proactive disclosure of SOE information, including a list of SOEs, to be updated annually. ${ }^{24}$ Meanwhile, they clarify that content disclosed upon request covers information concerning SOEs or government monopolies, including information concerning shares or votes, personnel arrangements, revenue and assets, exceptions and immunities, and information related to non-commercial assistance and "equity capitals" 25 (regardless of whether the equity infusion constitutes non-commercial assistance) to SOEs. ${ }^{26}$

Fourth, non-commercial assistance rules, which have some similar characteristics to the subsidy rules in the SCM Agreement (for example, regulations in cases where such activity causes adverse effects or injury), are created to achieve a close integration of traditional subsidy rules with SOE rules, ${ }^{27}$ but with several improvements: (a) they extend the range of application to cover not only trade in goods, but also trade in services and covered investments; (b) they apply not only to the government's support of SOEs, but also to SOEs' support for SOEs, ${ }^{28}$ such as the provision of credit concessions by state-owned financial enterprises to SOEs, and non-SOEs' support for SOEs, such as the "indirect provision" ${ }^{29}$ of non-commercial assistance by non-SOEs which are entrusted or directed by the government. This, to a large extent, solves the problem of indirect subsidization; past WTO disciplines could not effectively restrain governmental assistance provided in cases of restructuring public or private enterprises; $;{ }^{30}$ and (c) both 
governments and enterprises, regardless of ownership, may be identified as entities of providing non-commercial assistance, defusing the difficulty of the SCM Agreement in identifying SOEs as public bodies.

Fifth, a stronger enforcement mechanism is established. A Committee on SOEs and Designated Monopolies (hereinafter Committee), composed of government representatives of each State Party, is established in both the CPTPP and the USMCA. The Committee assumes the responsibility of (a) reviewing and considering the operation and implementation of the SOEs Chapter; (b) consulting on matters arising under the SOEs Chapter; (c) developing cooperative efforts to both promote SOE disciplines in free trade areas and contributing to the development of similar disciplines in other regional and multilateral institutions; and (d) undertaking other such activities as the Committee may decide. ${ }^{31}$ In addition, in terms of dispute resolution, both the CPTPP and the USMCA explicitly refer to settling disputes concerning SOEs via domestic courts, ${ }^{32}$ and do not contain any exclusive terms regarding an application of state-state dispute settlement mechanism or investor-state dispute settlement ("ISDS") mechanism, thereby providing full possibilities for resolving disputes arising from SOEs through various channels.

Nevertheless, in addition to the above improvements, both the CPTPP and the USMCA provide a wider range of exceptions than the GATT/WTO disciplines. ${ }^{33}$ These exceptions mainly include two categories: one for specific subjects, such as small and medium-sized SOEs, ${ }^{34}$ sub-central SOEs, ${ }^{35}$ or other certain types of SOEs ${ }^{36}$ and the other for specific behavior, such as non-commercial activities of SOEs, government procurement activities, exercise of government functions, resolution of a failing or failed enterprise principally engaged in the supply of financial services, and non-conforming activities retained by the parties, etc. ${ }^{37}$

It is noteworthy that the CPTPP and the USMCA have a far-reaching impact on some recent trade agreements such as the CETA, the EPA and the EU-Vietnam FTA. For example, they all contain an SOE chapter; ${ }^{38}$ provide clearly defined commercial considerations and non-discriminatory treatment obligations covering both national treatment and MFN treatment; ${ }^{39}$ and expand the application of these obligations to comprise goods, services and investments, and provide extensive exceptions. ${ }^{40}$ In some ways, these recent agreements go further than the CРTPP and the USMCA. For example, SOE disciplines in the EPA and the EU-Vietnam FTA apply to SOEs at all levels of government, without exceptions for sub-central SOEs, 
as the CPTPP and the USMCA do. In addition, the EPA and the EU-Vietnam FTA specify a "regulatory framework," which is absent in the CРTPP and the USMCA. This framework focuses on three commitments of the Parties to: (a) observe internationally recognized standards of corporate governance; (b) ensure any regulatory body to be independent from and not accountable to any regulated enterprises, and acts impartially with regards to different types of enterprises; and (c) enforce laws and regulations in a consistent and non-discriminatory manner.

Overall, the 21st-century disciplines have indeed made up for the shortcomings of the traditional rules. These, however, may have some limitations as follows. First, the expansion of applicable subjects to SOEs and designated monopolies may still not cover all government supported market entities that may distort global trade. Also, whether an entity is an SOE or a designated monopoly is still subject to a case-by-case analysis. Second, they are inevitably accused of being 'discriminatory' towards SOEs, violating the basic principle of "ownership neutrality"; and (c) extensive exceptions actually weaken their effectiveness.

\section{China's Exploration OF THE SOE DisCiplines}

\section{A. China's Understanding of Competition Policy}

This part will attempt to explain China's exploration of SOE disciplines within the framework of competition policy. In the Chinese context, competition policy has at least two layers of meaning: in a narrow sense, it is synonymous with competition law; but more broadly, it covers all policies that are conducive to competition, that is, not only competition law as such, but also parts of other policies that contain content relating to "promoting competition."

In developed economies, such as the US and the EU, competition policy is primarily comprehended in a narrow sense. ${ }^{43}$ This situation is easy to understand, because these countries have relatively developed market economies and the free and fair competition has penetrated into most of their economic and social policies. For an examination of competition concerns, therefore, it is sufficient to examine competition law. In contrast, both scholarly and official opinion in China is increasingly inclined to consider competition policy in a broader sense. ${ }^{44}$ According to this perspective, such measures can be considered parts of competition policy 
involving pro-competition elements, such as $\mathrm{SOE}$ reforms to facilitate competition, industrial policy aiming at deregulation, trade policies concerning the reduction of tariff and non-tariff barriers, investment policies of relaxing market access and administrative procedures for examination and approval, and fiscal policies preventing specific subsidies, etc.

This understanding is strongly motivated because it promotes the fundamental position of China's competition policy. ${ }^{45}$ China has long given priority to industrial policy over competition policy and been accustomed to utilizing the former to develop its economy. Therefore, relying solely on competition law is not sufficient to eliminate anti-competitive conditions in other economic and social policies. In this regard, the mission of China's competition policy is not only an intensified implementation of competition law, but also the infiltration of the principle of free and fair competition into other economic and social policies, especially in industrial policy, in order to achieve an industrial policy that is pro-competitive. ${ }^{46}$ It is also reflected in China's goal of building a "competitive neutrality" system, ${ }^{47}$ which is in line with international SOE disciplines aiming to ensure the government to maintain 'neutrality' on market competition without bias towards specific market players (especially SOEs).

\section{B. International SOE Commitments}

\section{Multilateral Commitments}

In addition to the above-mentioned GATT/WTO disciplines, China made special commitments to SOEs in its WTO Protocol of Accession. These commitments fall into the following three categories. ${ }^{48}$ The first is, the direct mention of SOEs in the protocol, including: (a) within the section on subsidies, ${ }^{49}$ which lowers the criteria for identifying subsidies to SOEs as specific, thereby raising the chance of utilizing countervailing duties against Chinese SOEs; and (b) within the section on agriculture, ${ }^{50}$ which relates to transparency requirements for SOE subsidies in the agricultural sector. However, except for the emphasis on the agricultural sector, these requirements are basically in line with other transparency requirements in the GATT/WTO framework. The second is the discussion in the Report of the Working Party on the Accession of China (hereinafter Working Party Report). Though there are seven paragraphs in the Working Party Report that directly involve "stateowned and state-invested enterprises," only three commitments with regards to 
them ${ }^{51}$ are officially taken note of and incorporated under paragraph 342 among the conclusions of the Report. The third is an indirect mention in the Protocol referring to transparency requirement of subsidies. ${ }^{52}$ It requires China to notify the WTO of any subsidy within the meaning of Article I of the SCM Agreement. Because of the brevity of the Protocol, the international community tends to regard the Protocol as ineffective for resolving concerns about Chinese SOEs. ${ }^{53}$

\section{Bilateral and Regional Commitments}

By the end of August 2019, China had signed 16 free trade agreements ("FTAs"). All recent FTAs incorporated competition rules, ${ }^{54}$ though most of them only provide a principled stipulation of competition issues.

So far, China's FTA with South Korea ("China-ROK FTA") has the most detailed competition rules. It stresses the principles of transparency, non-discrimination, and procedural fairness in the competition law enforcement; ${ }^{56}$ introduces specific transparency requirements to ensure the publication of competition laws and regulations as well as any administrative decisions or orders; ${ }^{57}$ and refines forms of cooperation, including notification, consultation, information exchange, and technical cooperation. ${ }^{58}$

Nevertheless, no FTA China has participated in has a specific SOE chapter, though there did exist some competition rules that are SOE-related. For example, the China-ROK FTA indicates that the competition chapter applies to all undertakings of each Party, including public enterprises and enterprises entrusted with special rights or exclusive rights, in so far as such application does not obstruct the performance, in law or in fact, of the particular tasks assigned to them. ${ }^{59}$ The Agreement on Trade in Service of the Framework Agreement on Comprehensive Economic Co-operation Between the People's Republic of China and the Association of Southeast Asian Nations ("China-ASEAN Agreement on Trade in Service") also imposes specific obligations on monopolies and exclusive service suppliers to ensure: (1) they act in a manner consistent with any Party's obligations under specific commitments; (2) they do not abuse their monopoly positions in a manner inconsistent with such commitments; and (3) any Party may request another Party to provide specific information concerning their operations. ${ }^{60}$

The above provisions contain the goal of promoting "fair competition," which is consistent with the principle of competitive neutrality and the 21 st-century 
SOE disciplines. However, these provisions only apply to the implementation of competition law, and are not designed to solve trade or competition distortion effects of SOEs. In a strict sense, they are not SOE disciplines in the end.

There are two main reasons for the absence of specific SOE rules in China's current bilateral and regional agreements. First, China has concluded agreements mainly with developing economies. ${ }^{61}$ They are usually more concerned about traditional trade issues and are not capable of requiring China to accept higher standards of commitments. Second, China is reluctant to accept specific SOE disciplines before it has carried out adequate domestic reforms and formed corresponding institutions, which could effectively respond to the adverse effects of SOE disciplines. However, with the continuous improvement of China's competition policy and the further deepening of SOE reforms, it is foreseeable that more detailed competition rules, including competitive neutrality rules, or even SOE disciplines, may be incorporated into future regional or bilateral agreements in which China participates. For instance, the negotiations on the China-Japan-ROK FTA are in full swing. ${ }^{62}$ Given that Japan is a CPTPP member, and South Korea has signed FTAs with the US and the EU respectively, they are likely to propose more stringent disciplines than existing China's FTAs to integrate, inter alia, SOE topics into the proposed agreement.

\section{Domestic Measures}

\section{SOE Reforms}

SOE reforms have always been an essential part of China's reform and openingup measures in the last four decades. The author would refrain from enumerating the stages of China's SOE reforms because many scholars have already described them. ${ }^{63}$ In sum, the reform process basically follows a consistent line, though experiencing some twists and turns in the course toward corporatization, marketization, and modernization.

Among the SOE reforms carried out in history, two measures have had profound impacts and deserve particular attention. The first one is the strategic readjustment of SOEs commenced in 1995. It shifted focus from SOE reforms of individual enterprises (single invigoration) to the entire state-owned economy (integrated invigoration). This reform was carried out in accordance with the principle of "grasping the large and letting go of small." This means that the State remained 
control over only 'large' SOEs, ${ }^{64}$ while small and medium-sized SOEs were privatized. It may be one of the most successful market-oriented SOE reforms to date since it achieved Pareto improvement by letting relevant competent authorities remove operational burdens and financial pressures, while managers and workers within the enterprises benefited from enhanced efficiency after privatization.

Another success was the establishment of the state-owned asset management system. China established the State-owned Assets Supervision and Administration Commission ("SASAC") in March 2003, and all its corresponding local branches before the end of 2007. This reform unified the supervisory system of SOEs, but possibly deviated from the basic direction set by the strategic readjustment reform. On the one hand, the SASAC and its local branches have multiple roles as: investors on behalf of governments at different levels; regulators supervising the operation of state-owned assets; and policymakers formulating relevant supervision and management rules. ${ }^{65}$ This interleaving of multiple duties has resulted in a selfmonitoring paradox, i.e., they exist both as athletes and referees. On the other hand, as the de facto owner of state-owned assets, the SASAC and its local branches form a "community of interest" with related invested and supervised SOEs, which creates favourable conditions for SOEs to seek administrative monopoly power.

The foregoing reforms set the foundation for the current round of SOE reforms which unveiled with the Decision on Matters on Comprehensively Deepening Reform (hereinafter Decision 2013) ${ }^{66}$ adopted by the Third Plenum of the 18th Party Congress, and further promoted with the Guiding Opinions on Deepening the Reform of State-Owned Enterprises (hereinafter Guiding Opinions) ${ }^{67}$ later jointly issued by the Central Committee of the Party and the State Council. The new round of reforms responds to the demands of the international community for the SOE disciplines in at least four aspects.

Firstly, the current reform divides SOEs into "Commercial SOEs" and "Public Welfare SOEs" so as to realize classified development, supervision and assessment. ${ }^{68}$ Commercial SOEs are further classified into two categories. One is the SOEs whose core business falls within industries and fields of sufficient competition ("Competitive Commercial SOEs"). Here, a majority of private shareholding is allowed, and their performance is assessed based on business indicators such as revenue and profits, the value of state-owned assets and market competitiveness. The other is the SOEs whose core business belongs to major industries and key fields concerning 
national security, national economic lifelines, or special projects (hereinafter Special Commercial SOEs), in which the State shall maintain the position as the controlling shareholder, though the participation of private capital is encouraged, and the evaluation of such SOEs hinges on not only the indicators applicable to Competitive Commercial SOEs, but also other aspects, such as their efforts to serve national strategies, safeguard national security and the operation of the national economy, develop cutting-edge strategic industries, and complete special tasks. ${ }^{69}$ Conversely, Public Welfare SOEs aim to serve the society at large providing public goods and services. They are allowed to be wholly state-owned or pursue ownership diversification in the light of their own conditions. In this regard, their assessment focuses on social contributions such as cost control, and product and service quality, with public evaluation as one of the important reference indicators. ${ }^{70}$

Secondly, the reform accelerates the corporatization of SOEs and optimizes their structure of corporate governance. According to the requirements of the State Council, all central SOEs supervised by the SASAC should have been restructured to limited liability companies or joint stock limited companies in accordance with the Company Law by the end of $2017 .^{71}$ The latest data shows that all SOEs at the central level and 94 percent at the sub-central level have completed this corporatization reform. ${ }^{72}$ This reform intends also to strengthen the operation and management of SOEs in a market-oriented manner, such as encouraging SOEs to adopt a market-based remuneration distribution mechanism, introduce a marketoriented selection and employment mechanism to recruit and select the management personnel, and give full power to the decision-making role of the board of directors, the supervisory role of the board of supervisors, and the operation and management role of the executives. ${ }^{73}$

Thirdly, the current reform highlights the development of a mixed ownership economy. ${ }^{74}$ On the one hand, it encourages the injection of non-state-owned capital (including domestic and foreign capital) into SOEs and the participation of non-state capital in their restructuring and management. On the other hand, it also promotes state-owned capital to invest in private enterprises focusing on public services and strategic industries. Moreover, for the purpose of realizing equity diversification, employee shareholding is also explored in mixed ownership enterprises. ${ }^{75}$ According to the data disclosed by the SASAC, the mixed ownership reform has achieved positive results by the end of 2018: (a) in terms of quantity, 70 percent of the current 
central SOEs and their sub-enterprises have been mixed; (b) in terms of owner's equity, non-state-owned capital has accounted for 36 percent of central SOEs; and (c) as one of the typical mixed ownership forms, listed companies have accounted for 65 percent, 61 percent and 88 percent of central SOEs in terms of total assets, revenue, and profits, respectively. ${ }^{76}$

Fourthly, the reform has made some considerable breakthroughs with regards to the state-owned asset management system. ${ }^{77}$ One of its most groundbreaking practices has been its development of a list of supervisory powers and responsibilities. ${ }^{78}$ Following this practice, SASAC and its local branches are only entitled to exercise investor duties or supervision based on the list, with the rest of the powers and responsibilities reserved for SOEs themselves, so as to expand the business autonomy of SOEs. ${ }^{79}$ The reform also creates two types of companies, namely, State-owned Capital Investment Companies ("SCICs") and State-owned Capital Operation Companies ("SCOCs"), or collectively State-owned Capital Investment and Operation Companies ("SCIOCs"), ${ }^{80}$ which exercise the investment and operation functions of the SASAC and its local branches. Here, the SCICs primarily focus on the investment in new core or strategic industries, while the SCOCs do on the restructuring of existing SOEs. ${ }^{81}$ In addition, the reform is committed to state-owned capital being concentrated in strategic industries or key areas in order to promote the centralized and unified supervision of state-owned assets through establishing a state-owned capital budget management system covering all SOEs. ${ }^{82}$

Arguably, China's SOE reforms so far have created favourable conditions for both meeting the requirements of international SOE disciplines and establishing an SOE management system that conforms to the principle of competitive neutrality. First, SOE disciplines at the international level or at the competitive neutrality system that is implemented within a sovereign State (such as Australia), are only applicable to commercial SOEs. Therefore, the classification reform of SOEs creates the room for China to accept SOE disciplines or to develop its own competitive neutrality system in the future. Second, the reform to promote the modern enterprise system, in particular the corporatization of SOEs, has been regarded by the OECD as one of the most important measures to achieve competitive neutrality. ${ }^{83}$ Third, along with the mixed ownership reform, the reform of corporate governance structure enhances the autonomy of SOEs in terms of business decision-making and personnel appointments; results in more market-oriented checks and balances; and 
helps to promote the operation of SOEs on the basis of commercial considerations. Finally, the reform of the SOE management system, especially the creation of the SCIOCs, is expected to largely resolve the "multiple roles" dilemma of the SASAC and its local branches. SCIOCs are expected to be authorized directly by the government to perform the role of investors as a substitute for the SASAC and its local branches. This would reduce the agency's level and restore the SASAC and its local branches to purely supervisory organizations. This would reduce the possibility of the SASAC and its branches being 'captured. ${ }^{84}$

Of course, the above reforms cannot completely relieve the worries of the international community regarding the trade distortion effect of Chinese SOEs. One of the reasons lies in the fact that the new round of SOE reforms also strengthens the Party's control over SOEs while promoting marketization reform. For example, the Guiding Opinions require "strengthening and improving the Party's leadership over SOEs" by "incorporating the general requirements of the Party building work into the articles of association of SOEs and clarifying the legal status of the Party organizations in SOEs," and establishing a leadership system according to which "the members of the Party organizations may enter the board of directors, the board of supervisors and the managers. ${ }^{.85}$ Therefore, the Party organizations can involve in SOEs' personnel appointments and major decision-making. This intensifies doubts about the independence of SOEs in terms of commercial operations and decisions. Therefore, striking a balance between political control and market operation remains a huge challenge for China's SOE reforms. In addition, the goals of China's current SOE reforms are not yet fully aligned with those of SOE disciplines or competitive neutrality. There are no SOE reform initiatives that clearly prioritize the promotion of fair competition between SOEs and private enterprises. The appointment of Xiao Yaqing, the former Director of the SASAC, as Director of the newly formed unified competition authority, State for Administration for Market Supervision ("SAMR"), may be a positive sign, creating an opportunity for the integration of SOE reforms with competition policy.

\section{The Anti-Monopoly Law}

Some believe that Article 7 of the Anti-Monopoly Law ("AML") ${ }^{87}$ provides SOEs with "special protection," ${ }^{, 88}$ or the terminology is intentionally ambiguous in a global sense for flexibility in its implementation. ${ }^{89}$ Actually, this is not the case. The AML 
makes it clear that it protects only the "lawful business operations" of SOEs in industries deemed nationally important. In other words, SOEs that violate the AML should be regulated identically to other market entities. However, the ambiguity regarding what "lawful business operations" means does increase the uncertainty of the AML application, which may lead to the misunderstanding that the AML treats SOEs favorably. Thus, an Expert Proposal on revisions to the AML suggests deleting the emphasis on "the state-owned economic sector," stressing that the State shall protect the lawful business operations of all undertakings so as to avoid ambiguity.

In terms of implementation, the main challenge facing the AML is the criticism of selective enforcement. ${ }^{91}$ There have been many law enforcement cases against SOEs, ${ }^{92}$ but to date the enforcement actions were primarily brought against subcentral level SOEs, rather than central level SOEs under the supervision of the SASAC, ${ }^{93}$ though the Chinese competition authority has clarified that the AML treats SOEs, private enterprises, and foreign enterprises equally. ${ }^{94}$ In fact, there have been investigations against central SOEs, ${ }^{95}$ but these cases were usually suspended or terminated upon the acceptance of rectification commitments by these SOEs. This said, these commitments may achieve the restoration of competition and the protection of consumer welfare.

Meanwhile, on the one hand, critics may have over-estimated the extent of selective enforcement. On the other, China's competition authority does face pressure when confronting SOEs (especially central-level SOEs). For instance, the law enforcer may not have originally intended to settle and close an investigation against central SOEs, but do so as the result of lacking independence and authority to avoid interference from other higher-level authorities. ${ }^{96}$ In reality, some central SOEs have a higher administrative rank than the competition authority. ${ }^{97}$ This constitutes an invisible obstacle to the AML application to SOEs. One way to resolve this obstacle is to raise the rank of the competition authority, or at least to make it have the same level or even a higher level than the investigated SOEs, so as to truly realize the fundamental position of competition policy among economic policies. The integration of the former three competition authorities ${ }^{98}$ into a unified authority (SAMR) in 2018 provides an opportunity for enhancing law enforcement powers and capabilities and finally addresses the concern in this area.

Additionally, the AML adopts a unique chapter (Chapter V) on the prohibition 
of the "Abuse of Administrative Power to Eliminate or Restrict Competition" (hereinafter administrative monopoly). To a large extent, the monopoly power of SOEs comes from government authorization or intervention, so that the prohibition of administrative monopoly can actually cut off the source of SOEs obtaining monopoly power.

The AML lists various forms of administrative monopolies. ${ }^{99}$ In general, it has been a great achievement for the AML to be able to regulate administrative monopolies specifically. However, from the perspective of competition policy, there is still some space for improvement. First, the AML fails to address some types of administrative monopoly. For example, its attention is largely focused on 'regional' administrative monopoly (local protectionism). It means administrative actions impede the free flow of goods, services or factors, but with little involvement of 'sectoral' administrative monopoly (hereinafter sector protectionism). In this case, the barriers set by the sector authorities in terms of market access, price control, and investment approval, are important sources of SOEs obtaining competitive advantage. In addition, the AML does not mention state aids or subsidies, and is silent on "soft administrative guidance" or convert government conduct, which may facilitate cartels among SOEs. ${ }^{100}$

Second, in terms of public enforcement against administrative monopoly, the competition authorities have been vested with only the "power of suggestion." They are granted no power to impose penalties for the AML violations, but may only submit suggestions to a superior authority of the authority suspected of violating the AML to rectify the unlawful acts. ${ }^{101}$ Nevertheless, the power of suggestion has played a constructive role in the Chinese context. This is largely due to the disclosure of case information by competition authorities. ${ }^{102}$ Given the need to maintain their image, governments at all levels usually adopt the suggestions of competition authorities. However, giving the power to remedy the issue to other authorities rather than competition authorities weakens the effectiveness of the AML itself. Therefore, the Expert Proposal on the Revision of the AML recommends that:

the power of suggestion be further strengthened by requesting the relevant higher-level authorities "to submit written handling opinions to the competent authority within 20 days after receiving the suggestions, and if the suggestions are accepted, the higher-level authority should immediately stop the illegal act and submit a written decision to the 
competent authority within 30 days; and if the suggestions are rejected, the higher-level authority should explain the reason."

Meanwhile, the Revision Proposal supplements the responsibility of undertakings when they benefit from the administrative monopoly, thereby further reducing the possibility that a particular undertaking (especially an SOE) will obtain a monopoly interest because of an administrative monopoly.

Third, in terms of private enforcement of the AML, although there have been many administrative cases filed to the courts, the plaintiff won only one case so far. ${ }^{105}$ There are two main reasons for this phenomenon. For one thing, abstract administrative conduct are not actionable. ${ }^{106}$ Therefore, it is impossible to file an action against a policy measure formulated by an administrative agency to restrict competition. Moreover, when analyzing whether a government agency 'abuses' its administrative power, the court mainly adopts the "criterion of legitimacy" originated from the administrative law to judge whether the conduct of the agency is authorized by the superior authority or is in accordance with the legal procedure, rather than judging whether it may have the effect of excluding competition (hereinafter criterion of competition effect). This, from another point of view, reflects the importance of understanding competition policy in a broad sense, of expanding the scope of the cause of actions of the Administrative Litigation Law, and of applying the criterion of competition effect when handling administrative monopoly cases.

Finally, both public and private enforcement of the AML against administrative monopolies are only ex post measures. This is to say the AML can only be applied after an administrative monopoly has given rise to influential anti-competitive consequences. Thus, relying solely on the AML cannot prevent administrative monopolies in advance. It is essential to introduce other policies beyond competition law to make up for the deficiencies of the AML.

\section{The Fair Competition Review System}

The Fair Competition Review System ("FCRS") was established in accordance with the Opinions of the State Council on Establishing a Fair Competition Review System during the Development of a Market-oriented Review System (hereinafter FCRS Opinions) of June 2016. ${ }^{107}$ The FCRS was further refined by the (provisional) Rules for the Implementation of the Fair Competition Review System (hereinafter 
FCRS Implementation Rules) in October $2017 .^{108}$ It is a typical example of procompetitive competition policy beyond competition law. As the FCRS effectively supplements the AML as an ex ante form of regulating government activities, it has become an indispensable component of Chinese competition policy.

The FCRM shares a similar philosophy with the EU's State aid control system, but with some differences in terms of its applicable object and implementation mechanism. We can gain insight into the characteristics of the FCRM through comparing these two systems.

Unlike the EU system, which specifically points to state aid, ${ }^{109}$ the FCRS targets all regulations, rules, regulatory documents and other policy measures (hereinafter policy measures) that involve the economic activities of market players, including measures on market entry, industrial development, foreign investment attractions, bidding and bids, government procurement, business codes of conduct, qualification standards, etc. The FCRS focuses on reviewing whether policy measures have the effect of eliminating or restricting competition. To this end, the FCRS clarifies four general standards and eighteen specific standards, plus two miscellaneous provisions. $^{110}$

Meanwhile, the state aid control system adopts an external review mechanism, i.e., the European Commission ("EC"), responsible for examining whether aid is compatible with the internal market, and Member States are only allowed to grant aid after notifying and getting approval from the EC. Conversely, the FCRS takes self-review as its main method, following the principle of "whoever formulates a policy is responsible for its revision." ${ }^{111}$ This means that while policies and measures must undergo competition review during their formulation or drafting process, this process is undertaken by the policy-making authorities themselves, not by competition authorities or other independent organizations. ${ }^{1{ }^{12}}$

The FCRS features a review process without complaint channel for the review outcomes, which is contrary to the EU's State aid framework within which both the EC and Member States can resort to for justice and relief. Accordingly, the FCRS establishes a set of additional procedures to ensure effective implementation. First, either a written review must be produced, or the competition review will be designated as a failure. Second, in the course of competition review, policy-making authorities need to solicit the opinions or advice of stakeholder, the public, external experts, or competition authorities. Third, an Inter-Ministerial Joint Meeting 
System is built at both central and local government level to facilitate the review process. If it is difficult for distinct departments to coordinate their opinions, they can submit disputes in the joint meeting for coordination. Furthermore, policymaking authorities must submit an annual implementation report to the office of the joint meeting every year. Finally, a periodic evaluation mechanism ensures that the policy measures issued after the competition review are assessed every three years or at the policy-making authority's own discretion. If discretion were given to the policy-making authorities, an evaluation period is required to be specified in the policy measures. The policy-making authorities are also encouraged to entrust thirdparty professional bodies to carry out assessments, which, to a large extent, helps to further enhance the validity of FCRS. ${ }^{113}$

Overall, the FCRS has performed positively. By the end of 2018, the FCRS had been deployed and actualized in all departments of the State Council, all provincial governments, 98 percent municipal governments and 85 percent county governments. Moreover, governments at different levels reviewed numerous both incremental and existing documents. For example, in 2018, a total of 310,000 incremental documents were reviewed (up 154 percent from 2017), and more than 1700 documents were revised and improved (up 157 percent from 2017). Furthermore, 820,000 existing documents were sorted out and more than 20,000 documents which were suspected of local protectionism, designated transactions and market barriers were cleared up. ${ }^{114}$

It is undeniable that there are still some drawbacks of the FCRS which need to be overcome. The self-review mechanism is subject to the most criticism, because the cost of self-review is assumed by the review area alone, while the benefit of selfreview is shared by all areas, including those who have undertaken no review or only superficial review. It eventually results in the lack of initiative to implement the FCRS seriously. Given that the competition authority does not yet possess adequate expertise and capability to carry out such large-scale review work, and considering the complexity of competition review, it is realistic and reasonable to adopt the current mechanism in the initial stage of implementing the FCRS. It is also a good opportunity for policy-making authorities to undertake competition advocacy. Once most of the existing policy measures have been polished and the capacity of the competition authority is improved, there would be probably a gradual transition to a review mechanism that is led by the competition authority or a specialized review 
organization. $^{115}$

Additionally, the FCRS provides extensive exceptions for the sake of maintaining national economic safety, cultural security, or national defense, relieving poverty or natural disasters; and preserving energy resources and the environment, ${ }^{116}$ but without specific criteria for clearly identifying such exceptions. This creates room for policy-making authorities to abuse exceptional provisions, such as applying arbitrary exceptions to policy measures that do not meet the applicable conditions. Nevertheless, the FCRS also explicitly stipulates that a policy measure falling into the scope of exceptions shall meet following three additional conditions: (a) it is indispensable to achieve the policy goal; (b) it would not severely exclude and restrict market competition; and (c) it has a fixed period of implementation. ${ }^{117}$ This largely prevents the abuse of this system.

As a result, the FCRS creates conditions for the integration of SOE disciplines into China's policy framework. Like the EU's state aid control system, though the FCRS does not aim directly at SOEs, its review standards and enforcement actually have the institutional and practical effect of regulating SOEs. The review standards have embodied some principles of competitive neutrality, such as tax neutrality (arrangement of financial expenditure shall not be linked to tax or non-tax revenue paid by enterprises), subsidy neutrality (discriminatory price or subsidy policies shall not be imposed on non-local or imported goods and services), credit neutrality (preferential policies shall not illegally be granted to specific undertakings), and regulatory neutrality (unreasonable and discriminatory conditions for market access and exit shall not be set up), etc. Undoubtedly, the implementation of FCRS will provide experience for China's adoption of SOE disciplines, laying a foundation for the formulation of China's competitive neutrality system.

\section{Disciplining SOEs WITHIN A REDEFINED Framework of Competition Policy}

\section{A. The Necessity to Discipline SOEs under the Competition Policy Framework}

The current SOE disciplines are constructed on the basis of trade distortions and as a part of trade rules. But SOEs are necessarily regulated not only because they are trade-related, but also because they may give rise to negative impacts on global 
competition. Nevertheless, competition law as such is generally believed to be ineffective in relieving the concerns posed by SOEs for the following reasons: (a) there has been no international competition law, therefore relying solely on domestic competition law would lead to a fragmentation of SOE rules; (b) competition law is mainly aimed at market-based enterprises whose primary goal is maximizing profits, but this is not the situation of SOEs; (c) competition law only exists as an $e x$ post remedy mechanism and thus is unable to regulate SOEs systematically; and (d) competition restrictions carried out by SOEs usually have a legal or policy basis, so that they can easily obtain immunity by resorting to the doctrine of state defense. ${ }^{118}$

The above reasons are one-sided or incomplete when viewed from a broader perspective informed by the competition policy framework. International competition rules with legal force, although not yet agreed to, may emerge in the future after a series of efforts, for instance by integrating the issues of SOEs into the framework of competition policy. The inability of the current multilateral trade framework to do so increases this possibility. Under the competition policy framework (including but not limited to competition law), the deviation of SOEs from the goal of profit maximization may be alleviated through the reform of SOEs, such as reforms on classification and corporate governance, as well as rule enhancement, such as increasing transparency and preventing the cross-subsidy of SOEs. ${ }^{119}$

In fact, even the competition law itself contains factors of ex ante regulation. For example, the notification and review of the concentration of undertakings can respond to the possible anti-competitive impact of mergers and acquisitions of SOEs. Moreover, broader competition policy would include other ex ante measures, such as the FCRS, which can effectively prevent the introduction of special preferential policy measures for SOEs. Additionally, the state action defense would be increasingly required through the imposition of more stringent applicable conditions. ${ }^{120}$ SOE's monopoly authorizations would also be substantially reduced by promoting pro-competition industrial policies and constructing a competitive neutrality system. Finally, the scope of immunity under competition policy is more reasonable and narrower than that of trade policy. For instance, competition law immunity is usually given based on the precondition, so that it enables consumers to share interests. In addition, it should not severely restrict competition in a relevant market, but is absent in current SOE disciplines such as those in CPTPP or 
USMCA. $^{121}$

Competition policy involves three categories of acts: (a) the private restraint of competition, which is the area of traditional competition law; (b) the state restraint of competition (such as an administrative monopoly), which can be regulated by either the anti-monopoly law in an ex post way, or an ex ante competition review; and (c) the hybrid restraint of competition, existing as a combination of private and government restrictions, such as the use of SOEs as a tool to implement industrial policies, which can be constrained by introducing a competitive neutrality system. ${ }^{122}$ Currently, more focus is on private restraint, while state restraint and hybrid restraint are, to a large extent, ignored. If a more broadly defined framework of competition policy can be universally recognized in the international community, the problems of SOEs will be significantly alleviated. ${ }^{123}$

The following characteristics of competition policy further render the integration of SOE disciplines into a competition policy framework more acceptable to all stakeholders. First, regarding the SOE issues, the perspectives between trade policy and competition policy would have difference. The former cannot bypass the investigation of 'motivation,' including "business considerations," "noncommercial assistance" and other factors, which focus on the purpose of behaviors rather than the effect of behaviors, while the latter focuses on whether it has the 'effect' of excluding and restricting competition, that is, it is effect-oriented rather than motivation-oriented. ${ }^{124}$ It is clear that the latter is more concomitant with the nature of international rules. International law is entitled to pay attention to the 'effect' of behaviors, but the 'motivation' of behaviors customarily belongs to the scope of national economic sovereignty. ${ }^{125}$ Thus, it is almost impossible to reach an agreement. As a result, it is more reasonable to address SOE issues from the perspective of competition policy than trade policy.

Second, in most jurisdictions, competition policy applies to any 'person' or 'undertaking' that engages in economic activity regardless of its ownership or legal form, ${ }^{126}$ which is also reflected in relevant FTAs. ${ }^{127}$ This is contrary to current SOE disciplines pertaining to specific subjects, such as SOEs, designated monopolies, or enterprises granted special rights or privileges. Thus, competition policy has a broader applicable scope than that of SOE disciplines within the trade policy framework. This accords with the intention of developed economies to expand the applicable scope of SOE rules in line with China's view of ownership neutrality. ${ }^{128}$ 
Third, a broad competition policy covers the whole process of SOEs regulation. Within the framework of competition law, the merger control system is a kind of $e x$ ante measure, preventing SOEs from monopolization, while other related systems, such as prohibiting monopoly agreements and abusing market dominance and administrative monopoly, can restrain the anti-competitive acts of SOEs after the event. ${ }^{129}$ Competition review systems, such as China's FCRS or the EU's state aid control system, can prevent governments from granting SOEs monopoly privileges or competitive advantages. Moreover, the competitive neutrality system can help to guide the reform of SOEs and the addressing of competition distortive effects of SOEs. $^{130}$

Finally, from the perspective of competition policy, ownership does not matter as long as the trading happens in competitive environments. ${ }^{131}$ In other words, competition policy adheres to the principle of ownership neutrality and focuses on how to improve the overall competitive environment, rather than giving special treatment to specific market players. ${ }^{132}$ This is consistent with the traditional concept of the WTO which is more acceptable to all parties.

\section{B. The Ways to Address SOE Concerns under the Competition Policy Framework}

Up to now, international competition policies have been explored via two basic routes or paths. One is the regulation of restrictive business practices by reaching binding competition rules (rule route), the other is the promotion of the convergence of competition policy through spontaneous international exchange and cooperation or competition advocacy (convergence route). ${ }^{133}$ Both paths are carried out at the multilateral, regional and bilateral levels.

As far as the rule route is concerned, the exploration at the multilateral level so far has been largely unsuccessful. Efforts to create international competition rules at the Havana Charter for an International Trade Organization failed in $1948,{ }^{134}$ leading to the retention of only some unsystematic competition-related rules within the current GATT/WTO framework. Since its establishment in 1995, the WTO has also made efforts to commence competition policy negotiations by establishing a Working Group on Trade and Competition Policy (WGTCP) to study issues relating to the interaction between trade and competition policy. However, it has proven difficult to incorporate competition issues into the WTO negotiating agenda. 
After a series of efforts, it was finally withdrawn from the negotiating agenda in $2004{ }^{135}$

At the regional and bilateral levels, the number of FTAs with competition chapters or law enforcement cooperation agreements is growing. However, they mainly involve procedural issues such as information disclosure and law enforcement cooperation. Regarding substantive rules and soft laws, each party has discretion as to whether or not to modify their domestic laws or take corresponding actions. ${ }^{136}$

Considering that binding competition rules are difficult to achieve in the short term, the convergence route becomes a priority. In this regard, the OECD, the UNCTAD and the ICN in particular have made the most influential contributions. Their efforts are mainly reflected in three aspects: (a) enhancing procedural convergence, especially in the area of merger control; (b) promoting substantial convergence, in particular advocating for core principles and rules on regulation of cartels, abuse of market dominance and concentrations of undertakings; and (c) competition advocacy. ${ }^{137}$ While the first two aspects are carried out within the scope of traditional competition law, competition advocacy and anti-competitive issues have been beyond its scope.

Regional or bilateral solutions, whether achieved by the rule route or convergence route, have their limitations, in terms of their limited coverage and content. They only cover the parties to the agreement, which are usually economies with similar competition policies, and thus cannot affect members outside the agreement. Meanwhile, they generally focus on basic principles (such as non-discrimination and transparency) and procedural issues (such as law enforcement cooperation), with little success in the course of constructing unified substantive rules. Thus, it seems more meaningful to explore competition rules or achieve convergence at the multilateral level. ${ }^{138}$

In this aspect, the author holds that the pluri-lateral approach should be prioritized. The WTO has the precedent of reaching competition rules aiming at a specific sector. The Basic Telecommunication Agreement, a part of the GATS, has a dedicated Annex, known as the Reference Paper, containing competition provisions specifically for the telecommunications sector. ${ }^{139}$ It imposes special obligations on major suppliers of basic telecommunications services, which often exists as SOEs. This offers a helpful instance of building competition policy in specialized areas.

In addition, due to changes in situation and concerns, many reasons resulting 
from the failure of multilateral competition rules no longer exist. For example, opposition from the US was once the biggest obstacle, ${ }^{140}$ while the US is currently one of the most active WTO members trying to solve the problem of SOEs. There has been a considerable change from 20 years ago, when there was an absence of competition law in many economies. At present, the vast majority of economies, including China, already have anti-monopoly laws and competition policies, whose distinctions have significantly narrowed as a result of convergence efforts. Also, redefined competition policy attends not only to business practices but also to government behavior. It therefore provides a space for reaching a consensus within the WTO framework. Consequently, it may be a sub-optimal approach to prevent SOEs from enjoying unfair competitive advantage by directly restricting government behaviors within the WTO system. ${ }^{14}$

A pluri-lateral agreement on competition policy should include at least the following aspects: (a) core principles such as non-discrimination, commercial considerations, etc., and other principles accepted by most parties, such as the principle of competitive neutrality and the principle of effect, etc.; (b) substantive rules: traditional competition rules and rules relating to administrative monopoly and competition review, etc.; (c) procedural rules such as notification and sharing of information, law enforcement cooperation, competition review cooperation, and transparency, ${ }^{142}$ etc.; and (d) a dispute settlement mechanism, indispensable to avoid pluri-lateral rules from being toothless. ${ }^{143}$ Some may argue that it is hard for all to accept such principles as competitive neutrality and effect, since these principles may extend the scope of competition policy to include broader industrial policy, which is different from the definition of competition policy traditionally recognized by the international community. As mentioned earlier, however, competition rules that only apply to non-regulated industries are inadequate to address SOE concerns. Thus, to understand and interpret competition policy in a broader sense can be a direction of efforts, though it may be difficult to arrive at a consensus in a multilateral or plurilateral setting in the short term.

Of course, there is still room for improvement in the convergence route. Convergence can only provide non-binding guidance for voluntary adoption by different jurisdictions. It neither focuses on substantive content, nor provides solutions to the jurisdiction conflicts that may arise from the extraterritorial application of competition law. Moreover, the OECD and the ICN have a limited impact on 
China who is not a member of either. Therefore, further efforts should be made by: (a) focusing not only on private competition restrictions, but also on restrictive competitive behaviors from SOEs or the government; (b) promoting best practices into domestic reform measures and domestic laws; (c) promoting peer review mechanisms which have been adopted by the OECD and the UNCTAD; ${ }^{144}$ and (4) promoting China's entry into the OECD and the ICN, or at least commencing studying China's issues on these two platforms.

\section{Conclusion}

Different economies have different views on how to address the trade or competition distortions that may be caused by Chinese SOEs. Given that SOE issues are not only trade-related, but also competition-involved, the trade policy framework should not be the only solution. Instead, the competition policy framework can serve as an alternative, or at least an important complement to existing SOE disciplines embedded in trade agreements for solving the problem of SOEs. Competition policy has a broader coverage with more neutral principles and more systematic regulatory system. All these characteristics make it easier than the alternatives for reaching a consensus among various parties. Efforts can be made in the following aspects.

At the international level, there could be an attempt to solve SOE issues within the framework of competition policy. For example, at the multilateral level, the feasibility of reaching a competition agreement can be envisaged in the form of pluri-lateral negotiations, while, at the bilateral or regional level, the incorporation of SOE disciplines into competition chapters of FTAs can be explored. However, no matter what form is taken, the basic logic and principles of competition policy should be followed to avoid the formation of new discriminatory treatment for SOEs.

At the domestic level, meanwhile, a variety of measures can be taken to strengthen the fundamental position of China's competition policy, including but not limited to: (a) embedding competition policy within the agenda for SOE reform; (b) modifying the AML to eliminate the controversial provisions for SOEs, by way of improving the ex-post regulation of administrative monopolies and promoting non-discriminatory law enforcement; (c) improving the fair competition review 
system and its implementation by gradually shifting from self-review to external independent review and third-party review; (d) carrying out capacity-building of the competition authorities and enhancing their authority and independence; and (e) promoting the construction of a Chinese competitive neutrality system.

\section{REFERENCES}

1. See, e.g., USTR, 2018 Report to Congress on China's WTO Compliance (2019), available at https://ustr.gov/sites/default/files/2018-USTR-Report-to-Congress-on-China\%27sWTO-Compliance.pdf; United States Department of Commerce, Memorandum on China's Status as a Non-Market Economy (2017), available at https://enforcement.trade. gov/download/prc-nme-status/prc-nme-review-final-103017.pdf; USTR, 2019 Trade Policy Agenda and 2018 Annual Report of the President of the United States on the Trade Agreements Program (2019), available at https://ustr.gov/sites/default/files/2019_Trade Policy_Agenda_and_2018_Annual_Report.pdf; and USTR, 2019 National Trade Estimate Report on Foreign Trade Barriers (2019), available at https:/ustr.gov/sites/default/ files/2019_National_Trade_Estimate_Report.pdf.

2. European Commission, WTO modernisation - introduction to future EU proposals (2018), available at http://trade.ec.europa.eu/doclib/docs/2018/september/tradoc_157331.pdf. See also European Commission, Commission Staff Working Document on Significant Distortion in the Economy of the People's Republic of China for the Purpose of Trade Defense investigations (2017), available at http://trade.ec.europa.eu/doclib/docs/2017/ december/tradoc_156474.pdf.

3. Between 12 December 2017 and 30 August 2019, the US, the EU and Japan released six joint statements for the purpose of strengthening their commitment to ensuring a level playing field globally. See the official website of the USTR, available at https://ustr.gov; see Joint Statement of the Trilateral Meeting of the Trade Ministers of the European Union, Japan and the United States (May 23, 2019), available at https://ustr.gov/about-us/policyoffices/press-office/press-releases/2019/may/joint-statement-trilateral-meeting.

4. European Commission, 2017 Document, supra note 2.

5. I. Willemyns, Disciplines on State-Owned Enterprises in International Economic Law: Are We Moving in the Right Direction? 19 J. InT'L Econ. L. 670 (2016).

6. See China's Proposal on WTO Reform: Communication from China (May 13 2019), available at https://docs.wto.org/dol2fe/Pages/FE_Search/FE_S_S009-DP.aspx?language= E\&CatalogueIdList $=254127 \&$ CurrentCatalogueIdIndex $=0 \&$ FullTextHash $=371857150 \& \mathrm{H}$ 
asEnglishRecord $=$ True $\&$ HasFrenchRecord $=$ False $\&$ HasSpanishRecord $=$ False .

7. GATT art. XVII. For details, see A. Mastromatteo, WTO and SOEs: Article XVII and Related Provisions of the GATT 1994, 16 WorLd TRADE Rev. 606 (2017).

8. Panel Report, Canada-Measures Relating to Exports of Wheat and Treatment of Imported Grain, $\mid 6.48$ and 6.50, WTO Doc. WT/DS276/R (adopted Sept. 27, 2004).

9. GATT art. XVII.1(a).

10. E.g., the US persistently accuses China of failing to fully fulfill its obligations to notify the WTO members about its STEs. See USTR, supra note 1, at 103.

11. GATS art. XVII.

12. Id.

13. Hyo-young Lee, Applying Competition Policy to Optimize International Trade Rules, KIEP Research Paper, Staff Papers 17-01 (Feb. 27, 2017), available at https://ssrn.com/ abstract $=2929110$.

14. Appellate Body Report, United States-Definitive Anti-Dumping and Countervailing Duties on Certain Products from China, WTO Doc. WT/DS379/AB/R (adopted Mar. 25, 2011). See also Appellate Body Report, United States-Countervailing Measures on Certain Hot-Rolled Carbon Steel Flat Products from India, WTO Doc. WT/DS436/AB/ R (adopted Dec. 19, 2014).

15. Appellate Body Report, United States-Countervailing Measures on Certain Hot-Rolled Carbon Steel Flat Products from India, \ 4.43-46, WTO Doc. WT/DS436/AB/R (adopted Dec. 19, 2014).

16. Appellate Body Report, United States-Countervailing Duty Measures on Certain Products from China, ๆ 5.100, WTO Doc. WT/DS437/AB/R (adopted July 16, 2019).

17. See the text of CPTPP, available at https://www.mfat.govt.nz/assets/CPTPP/Comprehensiveand-Progressive-Agreement-for-Trans-Pacific-Partnership-CPTPP-English.pdf.

18. The term 'indirectly' here refers to situations in which a Party holds an ownership interest in an enterprise through one or more state enterprises of that Party. See Note 7 of USMCA ch. 22, available at https:/ustr.gov/sites/default/files/files/agreements/FTA/USMCA/Text/22_ State-Owned_Enterprises.pdf.

19. СРTPP art. 17.1 \& USMCA art. 22.1.

20. СPTPP art. 17.4(1) \& USMCA art. 22.4 (1).

21. "Commercial considerations" may be "factors that would normally be taken into account in the commercial decisions of a privately owned enterprise in the relevant business or industry." See CPTPP art.17.1 \& USMCA art. 22.1.

22. СРTPP art. $17.4 \&$ USMCA art. 22.4.

23. See note 9 of CPTPP ch. 17, and USMCA art. 22.2(1).

24. СPTPP art. 17.10(1)(2) \& USMCA art. 22.10 (1)(2).

25 . Equity capital is a newly enumerated disclosure requirement which has only appeared in the USMCA. See USMCA art. 22.10 (4). 
26. СРTPP art. 17.10(3)(4)(5) \& USMCA art. 22.10(3)(4)(5).

27. СРTPP art. 17.6-8 \& USMCA art. 22.6-8.

28. CPTPP art.17.1 \& USMCA art. 22.1.

29. See Note 18 of CPTPP ch. 17 \& Note 18 of USMCA ch. 22.

30. For details on the WTO jurisprudence on indirect subsidization, see Appellate Body Report, USCountervailing Duty Investigation on Dynamic Random Memory Semiconductors (DRAMS) from Korea, WTO Doc. WT/DS296/AB/R (adopted June. 27, 2005). See also Panel Report, EC-Countervailing Measures on Dynamic Random Access Memory Chips from Korea, WTO Doc. WT/DS299/R (adopted Aug. 3, 2005).

31. CPTPP art. 17.12 \& USMCA art. 22.12.

32. СРTPP art. 17.5 \& USMCA art. 22.5.

33. GATT art. XVII.12 \& ad note to art. XVII.1(a) and art. XX(d).

34. CPTPP annex 17-A \& USMCA annex 22-A.

35. E.g., CPTPP annex 17-D and USMCA annex 22-D contain a list of the main obligations regarding non-discrimination, commercial considerations and non-commercial assistance. These do not apply to SOEs and designated monopolies at a sub-central level.

36. E.g., sovereign wealth funds, independent pension funds. See CPTPP art. 17.2 \& USMCA art. 22.2.

37. Id.

38. CETA ch. 18. The titles of both EPA ch.13 and EU-Vietnam FTA ch. 11 refer to "state-owned enterprises, enterprises granted special rights or privileges and designated monopolies." See the EU-Vietnam FTA, available at http://trade.ec.europa.eu/doclib/press/index. $\mathrm{cfm}$ ? id $=1437$.

39. CETA art. 18.4-5; EPA art. 13.5; \& EU-Vietnam FTA art. 11.4.

40. EPA art. 13.2 \& EU-Vietnam FTA art. 11.2, annex 11-A (Specific exception rules for Vietnam)

41. EPA art. 13.6 \& EU-Vietnam FTA art. 11.5.

42. Shiying Xu, Research on Competition Policy: International Comparison and China's CHorce [竞争政策研究: 国际比较与中国选择] 19-64 (Law Press 2013).

43. I. Destler \& H. Moran, U.S. Approach to International Competition Policy, Brookings Trade Forum, 395-8 (1998); U. Aydin \& K. Thomas, The challenges and trajectories of EU competition policy in the twenty-first century, 34(6) J. EUR. INTEGRATION 1-17 (2012).

44. Xianlin Wang, A Preliminary Study on the Basic Status of Competition Policy and its Main Realization Path [竞争政策的基础性地位及其主要实现路径初探], 5 Price Supervision and Anti-Monopoly in China [中国价格监管与反垄断] 24 (2016). India understands competition policy in the same perspective. See V. Singh, Failed WTO Platform for Competition Law Convergence: Evolving Alternate Regime of Mous on Internationalization of Competition Law, 54 Indian J. InT'L L. 251-2 (2014).

45. See the Circular of the State Council on Approving the NDRC's Opinions on Deepening 
Economic System Reform in 2015 [国务院批转发展改革委关于2015年深化经济体制改 革重点工作意见的通知], 26 Guo FA [国发] [May 8, 2015], available at http://www.gov.cn/ zhengce/content/2015-05/18/content_9779.htm; Several Opinions of the Central Committee of the Communist Party and the State Council on Promoting the Reform of the Price Mechanism [中共中央国务院关于推进价格机制改革的若干意见], Oct. 12, 2015, available at http://www.gov.cn/xinwen/2015-10/15/content_2947548.htm. The Central Economic Work Conference held in December 2018 further proposed to "strengthen the basic status of competition policy." See the Central Economic Work Conference was held in Beijing, Xi Jinping and Li Keqiang Made Important Speeches, Xinhuanet, Dec. 21, 2018, available at $\mathrm{http}: / / \mathrm{www} . x i n h u a n e t . c o m / p o l i t i c s /$ leaders/2018-12/21/c_1123887379.htm.

46. See, e.g., Xi Jinping, Speech at the Private Economy Symposium [在民营企业座谈会 上的讲话], Nov. 1, 2018, available at http://www.xinhuanet.com/politics/2018-11/01/ c_1123649488.htm.

47. See the 13th Five-Year Plan for Market Supervision [“十三五” 市场监管规划], 12 Guo FA [国发] (Jan. 12, 2017), available at http://www.gov.cn/zhengce/content/2017-01/23/ content_5162572.htm; Speech and Q\&A by President Yi Gang at the 2018 G30 International Banking Seminar [易纲行长在2018年G30国际银行业研讨会的发言及答问], XINwEI, Oct. 14, 2018, available at https://www.guancha.cn/economy/2018_10_14_475395. shtml; Yanran Zhu, SOEs reform is consistent with competitive neutrality and needs to advocate ownership neutrality [国企改革已符“竞争中性” 原则, 还要提倡“所有制中立”], available at https://www.yicai.com/news/100040010.html; Xiaoyu Li, Chinese Officials clearly Asserted China will Adopt Competitive Neutrality Policy [中国官方明确将采取竞 争中立政策], Nov. 6, 2018, available at https://baijiahao.baidu.com/s?id=16163690889888 $33143 \& w f r=$ spider\&for=pc; The State Council, Li Keqiang presided over the State Council Executive Meeting [李克强主持召开国务院常务会议], Mar. 26, 2019, available at http:// www.gov.cn/premier/2019-03/26/content_5376991.htm.

48. I. Philip, The Treatment of Chinese SOEs in China's WTO Protocol of Accession, 16 World Trade Rev. 643 (2017).

49. WTO, Accession of the People's Republic of China, WT/L/432 (adopted Nov. 23, 2001), ๑1 10.2 .

50. Id. $\uparrow 12.2$.

51. Working Party Report $9 \uparrow 46,47$ \& 49, available at http://unpan1.un.org/intradoc/groups/ public/documents/apcity/unpan002143.pdf.

52. WTO, supra note 49 , annex 5B.

53. Philip, supra note 48, at 635-53.

54. Only three FTAs contain competition chapters, namely, China-Iceland FTA, ChinaSwitzerland FTA, and China-ROK FTA.

55. Lile Wang, Regional FTA Competition Rules Negotiations: Status and Development [区 域自贸协定竞争问题谈判: 现状与发展], $11 \mathrm{~J}$. INT'L ECON. COOPERATION [国际经济合作] 
43-7 (2013).

56. China-ROK FTA art. 14.3 (Principles in Law Enforcement).

57. Id. art. 14.4 (Transparency).

58. Id. arts. 14.6 (Cooperation in Law Enforcement), 14.7 (Notification), 14.8 (Consultation), 14.9 (Exchange of Information), \&. 14.10 (Technical Cooperation).

59. Id. art. 14.5 (Application of Competition Laws).

60. China-ASEAN Agreement on Trade in Service, art. 7, available at http://fta.mofcom.gov. cn/dongmeng_phase2/annex/fwmyxieyi_en.pdf.

61. China has concluded FTAs with only 4 partners among the top 20 economies by GDP (nominal): South Korea, Australia, Indonesia, and Switzerland, and has not yet reached a FTA with any of the top 10 economies in the world. See C. Silver, Top 20 Economies in the World-Ranking the Richest Countries in the World, Investopedia, Nov. 19, 2019, available at http://unstats.un.org/unsd/methods/m49/m49regin.htm.

62. See China-Japan-ROK FTA negotiations look forward to new breakthroughs [中日韩自 贸协定谈判期待新突破], CoMnEws, Apr.12, 2019, available at http://fta.mofcom.gov.cn/ article/chinarihan/chinarhgfguandian/201904/40284_1.html.

63. For details on the history of China's SOE reforms, see Weihuan Zhou \& H. Gao \& Xue Bai, China's SOE Reform: Using WTO Rules to Build a Market Economy, 68 InT'L \& Comp. L. Q. 977-1022 (2019); Qunhui Huang, How 'New SOEs' Come of Age: Four Decades of China's SOE Reform 13 China Economist 58-83 (2018); Dong Zhang \& O. Freestone, China's Unfinished State-Owned Enterprise Reforms, 2 ECon. Roundur 77-99 (2013).

64. For details on large SOEs, see Decision of the Central Committee of The Communist Party of China on Major Issues Concerning The Reform and Development of StateOwned Enterprises [中共中央关于国有企业改革和发展若干重大问题的决定], Sept. 22, 1999, available at http://www.people.com.cn/GB/shizheng/252/5089/5093/ 5175/ 20010428/454976.html.

65. The SASAC and its local branches were empowered with their multiple roles. See Law of the People's Republic of China on State-owned Assets of Enterprises [中华人民共 和国企业国有资产法], Oct. 28, 2008, available at http://www.gov.cn/flfg/2008-10/28/ content_1134207.htm.

66. Decision of the Central Committee of the Communist Party of China on Matters on Comprehensively Deepening Reform [中共中央关于全面深化改革若干重大问题的决定], Nov. 12, 2013, available at http://www.gov.cn/jrzg/2013-11/15/content_2528179.htm.

67. Guiding Opinions of the Communist Party of China Central Committee and the State Council on Deepening the Reform of State-Owned Enterprises [中共中央、国务院关于深 化国有企业改革的指导意见], Aug. 24, 2015, available at http://www.gov.cn/zhengce/ 2015-09/13/content_2930440.htm.

68. Id. - 2. See also Guiding Opinions on the Functional Definition and Classification of 
State-Owned Enterprises [关于国有企业功能界定与分类的指导意见], Dec 30, 2015, available at http://www.gov.cn/xinwen/2015-12/29/content_5029253.htm.

69. Id. See also Jinpei Jia, Practice and Prospect of Classification Reform of State-owned Enterprises [国有企业分类改革的实践与展望], 10 ECON. GUIDE [经济导刊] 76-9 (2018).

70. Id.

71. Guiding Opinions of the General Office of the State Council on Further Improving the Corporate Governance Structure of State-owned Enterprises [国务院办公厅关于进-步完 善国有企业法人治理结构的指导意见], adopted Apr. 24, 2017, available at http://www. gov.cn/zhengce/content/2017-05/03/content_5190599.htm; Notice of the General Office of the State Council on Printing and Distributing the Implementing Plan for Corporatestyle Restructuring of Central Enterprises [国务院办公厅关于印发中央企业公司制 改制工作实施方案的通知], July 18, 2017, available at http://www.gov.cn/zhengce/ content/2017-07/26/content 5213271.htm.

72. Jianghong Gao, SASAC responded to the speeding up and efficiency enhancement of central SOEs and their adherence to the principle of competition neutrality [国资委回应 央企经济提速增效，坚持 “竞争中立” 原则], 21st CEnTURY Bus. HerALd, Oct. 17, 2018, available at $\mathrm{http}: / /$ wemedia.ifeng.com/82490009/wemedia.shtml.

73. Guiding Opinions, supra note 67, 93.

74. Opinions of the State Council on Development of an Economy of Mixed-Ownership of State-owned Enterprises [关于国有企业发展混合所有制经济的意见], adopted Sept. 23, 2015, available at http://www.gov.cn/zhengce/content/2015-09/24/content_10177.htm; Guiding Opinions on Encouraging and Regulating the Introduction of Non-State-owned Capital into Investment Projects of State-owned Enterprises [关于鼓励和规范国有企业投 资项目引入非国有资本的指导意见], adopted Oct. 26, 2015, available at http://tzs.ndrc. gov.cn/zttp/cjmjtcwj/201606/t20160607_806672.html.

75. Opinions on Piloting Employee Stock Ownership in State-owned Mixed-ownership Enterprises [关于国有控股混合所有制企业开展员工持股试点的意见]，adopted Aug. 2, 2016, available at http://tzs.ndrc.gov.cn/zttp/cjmjtcwj/201606/t20160607_806672.html.

76. See The State Council Information Office held a press conference on the economic performance of the central SOEs in the first quarter of 2019 [国新办就中央企业2019年 -季度经济运行情况举行发布会], XINHUANET, Apr. 16, 2019, available at http://www. xinhuanet.com/talking/20190416z/index.htm .

77. For details on the reforms of the state-owned asset management system, see Several Opinions of the State Council on Reforming and Improving the State Asset Management System [国务院关于改革和完善国有资产管理体制的若干意见], Oct. 25, 2015, available at http://www.gov.cn/zhengce/content/2015-11/04/content_10266.htm.

78. Notice of the General Office of the State Council on Forwarding the Plan of the SASAC for Promoting the Transformation of Functions with the Focus Put on Capital Management [国务 院办公厅关于转发国务院国资委以管资本为主推进职能转变方案的通知], May 10, 2017, 
available at http://www.gov.cn/zhengce/content/2017-05/10/content_5192390.htm.

79. Notice of the State Council on Issuing the Plan for Reforming the Authorized Operation System for State-owned Assets [国务院关于印发改革国有资本授权经营体制方案的通知], Apr. 28, 2019, available at http://www.gov.cn/zhengce/content/2019-04/28/content_5387112. htm.

80. Implementation Opinions of the State Council on Advancing the Pilot Program of the Reform of State Capital Investment and Operation Companies [国务院关于推进国有资 本投资、运营公司改革试点的实施意见], July 14, 2018, available at http://www.gov.cn/ zhengce/content/2018-07/30/content_5310497.htm.

81. Up to now, there has been 21 out of 97 SOEs supervised by the SASAC chosen as pilots of SCIOCs, of which 19 are SCICs and 2 are SCOCs. See Xueqing Wang, The Plan for the Reform of the State-owned Assets Management System is Released, and the Operation of the SCIOCs is Expected to Accelerate [国资授权经营体制改革方案出炉 投资运营公 司运作有望加速], Apr. 29, 2019, available at http://news.cnstock.com/news,yw-2019044369622.htm.

82. Supra note 79.

83. A. Capobianco \& H. Christiansen, Competitive Neutrality and State-owned Enterprises: Challenges and Policy Options, OECD Corporate Governance Working Paper No. 1, at 9 (2011), available at https://www.oecd-ilibrary.org/docserver/5kg9xfgjdhg6-en.pdf?expir es $=1564923887 \& \mathrm{id}=\mathrm{id} \&$ accname $=$ guest $\&$ checksum $=$ DC28F42F54E0365BA95B6BED 94157B59.

84. Xinhong Wang, On the Improvement of State-owned Assets Management System-the Position Adjustment of SASAC [论企业国有资产管理体制的完善-兼论国资委的定位调整 ], 10 PoL. \& L. [政治与法律] 129-41 (2015).

85. Guiding Opinions, supra note 67, ๆ 7; USTR, 2018 report, supra note 1, at 101-3.

86. Yaqing Xiao, who previously served as the Director of the SASAC, was appointed as the Party Secretary and Director of the SAMR on May 17, 2019. See Gaocheng Dai, 60-year-old Xiao Yaqing is in charge of the SAMR: the New Role and Challenges of the Promoters of SOE Reforms [60岁肖亚庆执掌市场监管总局: 国资改革推手的新角色新挑 战], THE PAPER [澎湃], May 19, 2019, available at https://www.thepaper.cn/newsDetail_ forward_3485657.

87. AML art. 7.

88. Xiaosong Xu, Reconstruction of the Legal System Framework for Monopolistic Stateowned Enterprises Supervision [论垄断国有企业监管法律制度框架的重构], 1 PoL. \& L. [政治与法律] 103-9 (2012). See also Yong Wang, the Paradoxical Anti-monopoly Law [吊论的反垄断法], 45 NEW CENTURY [新世纪] (2011).

89. H. Harris Jr. et al., Antimonopoly Law and Practice in China 196-7 (2011).

90. Expert Proposal on the Revision of the Anti-Monopoly Law of the People's Republic of China [《中华人民共和国反垄断法》专家修改建议稿], May 24, 2019, available at http:// 
www.competitionlaw.cn/info/1138/26864.htm.

91. USTR, 2019 Report, supra note 1, at 118.

92. See the speech delivered by Zhenguo Wu, the Director of the Anti-Monopoly Bureau of the SAMR, at the press conference on the theme of "the tenth anniversary of the implementation of China's Anti-Monopoly Law," available at http://www.gov.cn/ xinwen/2018-11/16/content_5341034.htm\#2.

93. W. Kovacic, Competition Policy and State-owned Enterprises in China, 16 World Trade Rev. 693-711 (2017).

94. Supra note 92.

95. In November 2011, e.g., the National Development and Reform Commission launched an anti-monopoly investigation of China Telecom and China Unicom, accusing them of using their dominant position in the broadband access market to hinder the entrance of other operators to the market. See Xiaoye Wang, Rethinking the Alleged Monopoly Case of China Telecom and China Unicom [中国电信、中国联通涉嫌垄断案的再思考], 2(2) SJTU L. REv. [交通法学] 5-15 (2013).

96. Id.

97. Dayan Zhang, Media analysis on the appointment and selection model of executives in central SOEs [媒体解析央企 “一把手” 任命与选拔模式], ChINA NEWS WEEKLy [中国新闻周 刊], June 3, 2013, available at http://news.chengdu.cn/content/2013-06/03/content_1231966. htm?node $=16840$.

98. Before 2018, China had three competition authorities, namely, the National Development and Reform Commission, the State Administration for Industry and Commerce and the Ministry of Commerce.

99. AML arts. 32-37.

100. Zhangjiang Zhang \& Baiding Wu, Governing China's Administrative Monopoly under the Anti-monopoly Law: A Ten-Year Review (2008-2018) and Beyond, 15 J. COMPETITION L. \& ECON. 718-60 (2019).

101. AML art. 51.

102. E.g. SAMR, Announcement on Issuing the 2018 Typical Cases of the Abuse of Administrative Power to Exclude and Restrict Competition [市场监管总局关于发布 2018年市场监管部门制止滥用行政权力排除、限制竞争行为典型案例的公告], Dec. 29, 2018, available at http://www.saic.gov.cn/fldj/tzgg/qlpc/201903/t20190313_291971. html.

103. Expert Proposal on the Revision of the AML, supra note 90, art. 76.

104. Id. art. 77

105. Shenzhen City Siweier Tech. Co. v. Guangdong Administration for Education (Guangdong Higher People's Court, June 28, 2017), available at http://fzzfyjy.cupl.edu. cn/info/1075/8239.htm.

106. The Administrative Litigation Law of the People's Republic of China of 2017 
(Administrative Litigation Law), art. 13.2, available at http://m.liuxiaoer.com/sj/3756. html.

107. Opinions of the State Council on Establishing a Fair Competition Review System During the Development of Market-oriented Review System [国务院关于在市场体系建设中 建立公平竞争审查制度的意见], June 1, 2016, available at http://www.gov.cn/zhengce/ content/2016-06/14/content_5082066.htm.

108. Rules for the Implementation of the Fair Competition Review System [公平竞争审查制度 实施细则], Oct. 23, 2017, available at http://www.gov.cn/xinwen/201710/5234731/files/ d78cf6b8b2d64bf0b4793bf334a04959.pdf.

109. State aid is defined as an advantage in any form whatsoever conferred on a selective basis to undertakings by national public authorities. See the official website of the EC, available at $\mathrm{http} / / / \mathrm{ec}$. europa.eu/competition/state_aid/overview/index_en.html.

110. Supra note 108.

111. Michael Gu \& Sihui Sun, New Review System Milestone for Fair Market Competition, Sept. 23, 2016, available at http://en.anjielaw.com/downloadRepository/aac39371125a-47f7-bae7-4597db2c5f9b.pdf.

112. Id. See also supra note 108.

113. Guidelines for the Implementation of Third-Party Assessment of Fair Competition Review [公平竞争审查第三方评估实施指南], Feb. 12, 2019, available at http://gkml. samr.gov.cn/nsjg/bgt/201902/t20190216_288666.html.

114. SAMR, The announcement of the overall implementation situations of the fair competition review system in 2018 [市场监管总局公布公平竞争审查制度2018年总体落实情况], Jan. 27, 2019, available at $\mathrm{http}: / / w w w . g o v . c n / x i n w e n / 2019-01 / 27 /$ content_5361519.htm.

115. Shanming Jin, Institutional Review and Path Optimization of the Fair Competition Review Mechanism [公平竞争审查机制的制度检讨及路径优化], 12 LEGAL ScI. [法学] 3-17 (2019).

116. FCRS Implementation Rules, art. 4.4.

117. Supra note 107.

118. Supra note 5.

119. Pinguang Ying, Competitive Neutrality: China's Practice and Outlook [竞争中立: 中国 的实践与展望], 12 CHINA WTO TRIBUNE [WTO经济导刊] 89-92 (2014).

120. See Report of the State Action Task Force, Sept. 2003, available at file://Users/ peterying/Downloads/stateactionreport_0.pdf; Parker v. Brown, 317 U.S. 341 (1943), and California Retail Liquor Dealers Ass'n v. Midcal Aluminum Inc., 445 U.S. 97 (1980); Consiglio Nazionale degli Spedizionieri Doganali v Comm'n (CNSD), Case T-513/93, 2000 E.C.R. II-01807; Consorzio Industrie Fiammiferi v. Autorità Garante della Concorrenza e del Mercato (Italian matches), Case C-198/01, 2003 E.C.R. I-8055.

121. Pinguang Ying, The Exemption of the Anti-monopoly Law-China's Perspective and Choice[反垄断法的豁免一中国的视角和选择], 16 J. Central South U. (Social Sciences 
Edition) [中南大学学报 (社会科学版)] 53-7 (2010).

122. F. González de Cossío, International Aspects of Competition Law, available at http:// www.unis.edu.gt/ap/fetch/international-competition.pdf.

123. Pinguang Ying, What kind of Competitive Neutrality does China need? Comparison and Enlightenment of Different Positions [中国需要什么样的竞争中立?-不同立场之比较及 启示], 3 Price Supervision And Anti-Monopoly In China [中国价格监管与反垄断] 2731 (2015).

124. Zhiwei Zhang \& Pinguang Ying, A New Exploration of Administrative Monopolies from the Perspective of Anti-monopoly Law [反垄断法思维下的行政性垄断新探], $88 \mathrm{~J}$. JIANGXI U. Fin. \& ECON. [江西财经大学学报] 104-10 (2013).

125. Quan Xu, Analysis on the Development Trend of the Principle of Economic Sovereignty [经济主权原则的发展趋向论析], 27 Mod. LEGAL SCI. [现代法学] 176-81 (2005).

126. The International Competition Network's 2014 Survey, available at http://www. icnmarrakech2014.ma/images/SOE_under_competition_law_Morocco.pdf. See also E. Fox \& D. Healey, When the State Harms Competition - The Role for Competition Law (New York University Law and Economics Working Papers No. 336, 2013), available at http://lsr.nellco.org/nyu_lewp/336.

127. E.g, China-ROK FTA uses the term 'undertaking,' while CPTPP and USMCA use the term 'person.' See China-ROK FTA art. 14.13; CPTPP art. 1.3; USMCA art. 1.4.

128. Yanran Zhu, The Reform of SOEs has Conformed to the Principle of "Competitive Neutrality" and Must Promote "Ownership Neutrality" [国企改革已符 “竞争中性” 原 则, 还要提倡 “所有制中立”], CBN, Oct.15, 2018, available at https://www.yicai.com/ news/100040010.html.

129. Pinguang Ying, Competition Policy under the Rule of Law Perspective [法治视角下的 竞争政策] 211-6 (Law Press 2013).

130. Pinguang Ying, A New Regulation Mode on Administrative Monopoly from the Perspective of Competition Policy: From Ex-post Remedy to Ex-ante Control [竞争政策 视角下行政性垄断规制新模式: 从 “事后救济” 到 “事前控制”] 106 J. JIANGXI U. Fin. \& ECON. [江西财经大学学报] 119-26 (2016).

131. M. Omran, The Performance of State-Owned Enterprises and Newly Privatized Firms: Does Privatization Really Matter?, 32 World Dev. 1038 (2004).

132. Supra note 129, at 217.

133. Pinguang Ying, Study on Chinese Competition Policy [中国竞争政策研究] (Law Press 2020, forthcoming).

134. Havana Charter for an International Trade Organization 1948, ch. V, U.N. Doc. E/Conf. 2/78, available at $\mathrm{http} / /$ www.wto.org/english/docs_e/legal_e/havana_e.pdf.

135. See the Decision Adopted by the General Council on 1 August 2004, WTO Doc. WT/ L/579 (adopted Aug. 2, 2004).

136. Singh, supra note 44, at 262. 
137. Zanlin Ruan \& Pinguang Ying, Antimonopoly Law: Principles, Diagrams, Cases AND Judicial Examination [反垄断法: 原理 ·图解 ·案例 ·司考] 392-406 (Chinese Democracy and Legal Press, 2015).

138. Supra note 122.

139. See the Reference Paper, available at https://www.wto.org/english/tratop_e/serv_e/ telecom_e/tel23_e.htm.

140. On the grounds of the US's objection, see supra note 122.

141. Fox \& Healey, supra note 126.

142. Some believe that transparency is likely to be a better discipline on the spillovers associated with SOEs than a search for binding rules. See R. Wolfe, Sunshine over Shanghai: Can the WTO Illuminate the Murky World of Chinese SOEs?, 16 WORLD Trade Rev. 713-32 (2017). In addition, the EU Transparency Directive can provide a useful reference. See Commission Directive of 16 November 2006 on the transparency of financial relations between Member States and public undertakings as well as on financial transparency within certain undertakings, art. 1, 2006/111/EC, OJ L 318 (Nov. 17, 2006).

143. Supra note 122.

144. Since 2003, the OECD Secretariat began to conduct peer reviews of competition policy of its members and non-member States. The UNCTAD also launched a voluntary peer review mechanism as part of its technical cooperation activities in 2005. 